\title{
Role of duodenogastroesophageal reflux in the pathogenesis of esophageal mucosal injury and gastroesophageal reflux symptoms
}

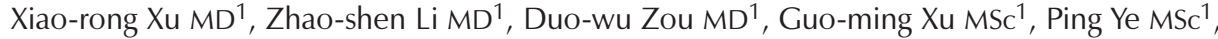 \\ Zhen-xing Sun $\mathrm{MSc}^{1}$, Qing Wang $\mathrm{MSc}^{2}$, Yan-jun Zeng $\mathrm{PhD}^{3}$
}

\begin{abstract}
$\mathrm{X} \mathrm{Xu}, \mathrm{Z} \mathrm{Li}, \mathrm{D}$ Zou, et al. Role of duodenogastroesophageal reflux in the pathogenesis of esophageal mucosal injury and gastroesophageal reflux symptoms. Can J Gastroenterol 2006;20(2):91-94.
\end{abstract}

BACKGROUND AND AIM: Patients with gastroesophageal reflux disease (GERD) usually suffer from acid reflux and duodenogastroesophageal reflux (DGER) simultaneously. The question of whether DGER has an important effect on the development of GERD remains controversial. The aim of the present study was to investigate the role of DGER in the pathogenesis of GERD and its value for the diagnosis of nonerosive reflux disease (NERD).

METHODS: GERD was initially diagnosed using the reflux disease questionnaire. For further diagnosis, results of the upper gastrointestinal endoscopy (excluding a diagnosis of Barrett's esophagus) were considered in conjunction with simultaneous $24 \mathrm{~h}$ esophageal $\mathrm{pH}$ and bilirubin monitoring.

RESULTS: According to endoscopic findings, 95 patients (43 men, $50 \pm 10$ years of age) were divided into two groups: the reflux esophagitis (RE) group $(n=51)$ and the NERD group $(n=44)$. Three DGER parameters, the percentage of time with absorbance greater than 0.14 , the total number of reflux episodes and the number of bile reflux episodes lasting longer than $5 \mathrm{~min}$, were evaluated in the study. For the RE group, the values of the DGER parameters $(19.05 \% \pm 23.44 \%, 30.56 \pm 34.04$ and $5.90 \pm 6.37$, respectively) were significantly higher than those of the NERD group $(7.26 \% \pm 11.08 \%$, $15.68 \pm 20.92$ and $2.59 \pm 3.57$, respectively, $\mathrm{P}<0.05$ for all) but no significant difference was found in acid reflux. Of NERD patients, $18.5 \%$ were diagnosed with simple DGER. The positive diagnosis rate of NERD could be significantly elevated from $65.9 \%$ to $84.1 \%$ $(\mathrm{P}<0.05)$, if bilirubin monitoring was employed in diagnosis.

CONCLUSIONS: DGER may occur independently but plays an important role in the development of RE and GERD symptoms. Simultaneous $24 \mathrm{~h}$ esophageal $\mathrm{pH}$ and bilirubin monitoring is superior to simple $\mathrm{pH}$ monitoring in helping identify patients at risk for NERD.

Key Words: Bilirubin monitoring; Duodenogastroesophageal reflux; Gastroesophageal reflux disease; Nonerosive reflux disease; $\mathrm{pH}$ monitoring

\section{Rôle du reflux duodénogastro-oesophagien dans la pathogenèse des lésions de la muqueuse de l'œsophage et du reflux gastro-oesophagien}

CONTEXTE ET BUT : Les patients souffrant de reflux gastro-
oesophagien (RGO) souffrent souvent, en même temps, de reflux acide et
de reflux duodénogastro-oesophagien (RDGO). La question de savoir si le
RDGO joue un rôle important dans l'apparition du RGO fait encore l'ob-
jet de controverse. La présente étude avait pour but de déterminer le rôle
du RDGO dans la pathogenèse du RGO et sa valeur dans le diagnostic du
reflux non érosif (RNE). MÉTHODE : Le RGO a d'abord été diagnostiqué à partir du questionnaire sur le reflux. On a ensuite tenu compte des résultats de l'endoscopie digestive haute (pour écarter un diagnostic d'œsophage de Barrett) ainsi que de ceux de la surveillance concomitante du $\mathrm{pH}$ et de la bilirubine dans l'œsophage, sur $24 \mathrm{~h}$, pour affirmer le diagnostic.

RÉSULTATS : Selon les résultats de l'endoscopie, 95 patients ( 43 hommes; âge : $50 \pm 10$ ans) ont été divisés en deux groupes : oesophagite par reflux (OR) $(n=51)$ et reflux non érosif $(n=44)$. Ont été évalués dans l'étude trois paramètres relatifs au RDGO, soit le pourcentage du temps au cours duquel l'absorption a été supérieure à 0,14 ; le nombre total d'épisodes de reflux et le nombre d'épisodes de reflux de bile d'une durée supérieure à 5 min. Dans le groupe d'OR, les valeurs des paramètres relatifs au RDGO $(19,05 \% \pm 23,44 \% ; 30,56 \pm 34,04$ et 5,90 $\pm 6,37$ respectivement $)$ étaient significativement plus élevées que celles dans le groupe de RNE $(7,26 \% \pm 11,08 \% ; 15,68 \pm 20,92$ et 2,59 $\pm 3,57$ respectivement; $\mathrm{P}<0,05$ pour tous), mais aucune différence significative n'a été enregistrée en ce qui concerne le reflux acide. Un diagnostic de RDGO simple a été posé dans $18,5 \%$ des cas de RNE. Le taux de diagnostic positif de RNE pourrait augmenter sensiblement et passer de $65,9 \%$ à $84,1 \%(\mathrm{P}<0,05)$ si la surveillance de la bilirubine était prise en considération dans la pose du diagnostic.

CONCLUSIONS : Le RDGO peut se produire seul, mais il joue un rôle important dans l'apparition des symptômes de l'OR et du RGO. La surveillance concomitante du $\mathrm{pH}$ et de la bilirubine dans l'œsophage, sur $24 \mathrm{~h}$, se montre supérieure à la simple surveillance du $\mathrm{pH}$ pour faciliter le repérage des patients prédisposés au RNE.

$\mathrm{D}_{\mathrm{r}}^{\mathrm{i}}$ uodenogastroesophageal reflux (DGER) is defined as regurgitation of duodenal contents through the pylorus into the stomach, with subsequent reflux into the esophagus (1). The role of DGER in the pathogenesis of gastroesophageal

reflux disease (GERD) is an interesting research area. It has been widely accepted that hydrochloric acid and pepsin are the primary gastroesophageal reflux agents predisposed to the development of esophageal symptoms and mucosal

${ }^{1}$ Department of Gastroenterology, Changhai Hospital, Second Military Medical University, Shanghai; ${ }^{2}$ Rehabilitation Engineering Centre,

The Hong Kong Polytechnic University; ${ }^{3}$ Institute of Biomechanics and Medical Information, Beijing University of Technology, Beijing, China Correspondence: Professor Yanjun Zeng, Beijing University of Technology, Beijing 100022, PR China. Telephone 8610-67391685,

fax 8610-67391975, e-mail yjzeng@bjpu.edu.cn

Received for publication April 3, 2005. Accepted July 14, 2005 
injury (2). However, the relationship between DGER and the development of GERD is controversial, especially the role of simple DGER without excessive acid reflux.

The diagnosis and quantification of DGER has traditionally been problematic. Previously, DGER was described with alkaline reflux. It has been demonstrated that a $\mathrm{pH}$ greater than seven does not correlate with reflux of duodenal contents (3). Recently, a new fibreoptic spectrophotometer, Bilitec 2000 (Synetics Medical, Sweden), has been developed for the detection of DGER independent of $\mathrm{pH}$ value. Today, Bilitec 2000 has greatly advanced the assessment of DGER in the clinical area and facilitated more accurate studies of disorders associated with DGER. Validation studies $(4,5)$ have confirmed a good correlation between Bilitec measurements and bile acid concentrations. Previous studies (6-8) using this device have provided accurate assessments of DGER.

GERD is a common disorder and can be divided into three relatively distinct groups: reflux esophagitis (RE); nonerosive reflux disease (NERD); and Barrett's esophagus (BE) (9). NERD patients complain about heartburn, regurgitation and other typical reflux symptoms, but no obvious mucosal changes are found by routine examination using upper gastrointestinal endoscopy. Compared with patients with clearly visible erosive lesions, such as RE, BE and peptic stricture, the diagnosis of NERD is, at times, more difficult to make. It is estimated that approximately $60 \%$ to $70 \%$ of GERD patients are NERD patients. However, there is no gold standard for the diagnosis of NERD. Esophageal pH studies, proton pump inhibitor tests and histology are not considered to be completely reliable (10-12).

The goal of the present study was to investigate the role of DGER in the pathogenesis of GERD, including mucosal injury and symptoms. In addition, we expected to evaluate the $24 \mathrm{~h}$ esophageal bilirubin monitoring using Bilitec device for the diagnosis of NERD.

\section{METHODS}

\section{Patient selection}

Patients who had experienced persistent heartburn or regurgitation symptoms for at least three months were considered eligible for the study. Patients with previous esophageal, gastric or biliary surgery, abdominal or thoracic radiotherapy, active gastrointestinal bleeding, esophageal or fundic varices, diabetes mellitus, Zollinger-Ellison syndrome, progressive systemic sclerosis, Raynaud's syndrome or other connective tissue disease, neurological disorders or malignant tumours were excluded. Patients were asked to fill out a detailed questionnaire about the severity and frequency of four symptoms including heartburn, acid regurgitation, food regurgitation and retrosternal pain. Each symptom was graded with severity $(0=$ absent, $1=$ mild, $2=$ mild to moderate, $3=$ moderate, $4=$ moderate to severe and $5=$ severe $)$ and frequency $(0=$ absent, $1=$ less than one day per week, $2=$ one day per week, $3=$ two to three days per week, $4=$ four to five days per week and $5=$ almost everyday). Patients receiving a total score of 12 or more were suspected of having GERD (13).

\section{Upper gastrointestinal endoscopy}

All subjects underwent an examination using classical upper gastrointestinal endoscopy. Reflux esophagitis was observed and graded according to the classical criteria of grades A to D (Los Angeles classification system). Patients with BE were excluded.
Simultaneous ambulatory esophageal $\mathrm{pH}$ and bilirubin monitoring and data analysis

Ambulatory esophageal $\mathrm{pH}$ and bilirubin monitoring (Digitrapper Mk III 2000, Synetics Medical, Sweden) was performed as reported in the literature $(14,15)$. The recorded data were analyzed using Synectics PM software. Acid reflux was defined as a decrease in esophageal pH below 4.0 and pathological DGER was defined as an increase in esophageal bilirubin absorbance less than 0.14 $(14,15)$. Acid and duodenal reflux were quantified separately with the following variables obtained from computerized analysis: the number of reflux episodes; the number of reflux episodes lasting longer than $5 \mathrm{~min}$; and the percentage of time with acid or duodenoesophageal reflux.

Normal values of ambulatory $\mathrm{pH}$ were determined according to previous results and the previous results of other investigators. In the present study, pathological acid reflux was considered present if the percentage of the time with intraesophageal $\mathrm{pH}$ less than four was greater than $4 \%$, the number of reflux episodes was greater than 50 or DeMeester value greater than 14.72. Pathological DGER was diagnosed if intraesophageal bilirubin absorbance was above 0.14 and the percentage of the time more than $2.53 \%$. The diagnosis criteria is consistent with those of other laboratories in China $(7,8)$.

\section{Statistical analysis}

Data were recorded as mean \pm SD. Data were statistically analyzed using Student's $t$ test or $\chi^{2}$ test. The results were considered significant when $\mathrm{P}<0.05$.

\section{Patients characteristics}

\section{RESULTS}

From January 2002 to January 2004, 95 patients (43 men and 52 women, mean $50 \pm 10$ years of age) were enrolled in the study. The scores of reflux disease questionnaire were greater than 12 for all patients. Eighty per cent of the patients complained of heartburn, $84 \%$ of acid regurgitation, $60 \%$ of chest pain, $58 \%$ of food regurgitation and $80 \%$ of epigastric discomfort.

\section{Upper gastrointestinal endoscopy}

Upper gastrointestinal endoscopy was performed. Forty-four patients without esophagitis or other esophageal lesions were diagnosed as having NERD. Endoscopic results showed abnormal findings in $51 \mathrm{RE}$ cases and, according to the Los Angeles classification of esophagitis, 18 were classified as grade A, 22 as grade $\mathrm{B}, 10$ as grade $\mathrm{C}$ and one as grade $\mathrm{D}$. There was no significant difference between the RE and NERD groups with regard to distribution of age, sex and symptom pattern.

\section{Ambulatory $24 \mathrm{~h}$ esophageal $\mathrm{pH}$ monitoring}

Key parameters of ambulatory $24 \mathrm{~h}$ esophageal $\mathrm{pH}$ monitoring were compared for RE and NERD patients, and no significant differences were found $(\mathrm{P}>0.05)$ (Table 1$)$.

\section{Ambulatory $24 \mathrm{~h}$ esophageal bilirubin monitoring}

The values of DGER parameters of RE patients were significantly higher than those of NERD patients $(\mathrm{P}<0.05)$ (Table 2).

\section{Analysis of simultaneous $24 \mathrm{~h}$ esophageal $\mathrm{pH}$ and Bilitec monitoring}

Acid reflux and DGER occurred simultaneously in $58.8 \%$ (30 of 51 ) of RE patients, while only $29.5 \%$ (13 of 44 ) of 
TABLE 1

Results of ambulatory $24 \mathrm{~h}$ esophageal $\mathrm{pH}$ monitoring in reflux esophagitis (RE) and nonerosive reflux disease (NERD) groups

\begin{tabular}{lcccc}
\hline Parameters & $\begin{array}{c}\text { Normal } \\
\text { value }\end{array}$ & RE group & NERD group & $\mathbf{P}$ \\
\hline $\begin{array}{l}\text { Percentage of time with } \\
\mathrm{pH}<4\end{array}$ & $<4$ & $16.30 \pm 19.42$ & $13.31 \pm 25.51$ & $\mathrm{NS}$ \\
$\begin{array}{l}\text { Number of reflux } \\
\text { episodes }\end{array}$ & $<50$ & $138.11 \pm 149.23$ & $111.86 \pm 116.90$ & $\mathrm{NS}$ \\
$\begin{array}{l}\text { Acid refluxes lasting } \\
>5 \text { min }\end{array}$ & $<3$ & $6.34 \pm 10.76$ & $5.52 \pm 7.89$ & $\mathrm{NS}$ \\
DeMeester score & $<14.72$ & $47.65 \pm 24.37$ & $43.21 \pm 21.96$ & $\mathrm{NS}$ \\
\hline
\end{tabular}

NS Not significant

TABLE 2

Results of ambulatory $24 \mathrm{~h}$ esophageal Bilitec (Synetics Medical, Sweden) monitoring in reflux esophagitis (RE) and nonerosive reflux disease (NERD) groups

\begin{tabular}{lccc}
\hline Parameters & RE group & NERD group & P \\
\hline $\begin{array}{l}\text { Percentage of time with } \\
\text { Abs }>0.14 \%\end{array}$ & $19.05 \pm 23.44$ & $7.26 \pm 11.08$ & 0.002 \\
$\begin{array}{l}\text { Number of bile } \\
\text { reflux episodes }\end{array}$ & $30.56 \pm 34.04$ & $15.68 \pm 20.92$ & 0.011 \\
$\begin{array}{l}\text { Bile refluxes lasting } \\
>5 \text { min }\end{array}$ & $5.90 \pm 6.37$ & $2.59 \pm 3.57$ & 0.002 \\
\hline
\end{tabular}

Abs Esophageal bilirubin absorbance

NERD patients had acid reflux combined with DGER $(\mathrm{P}<0.05)$. In contrast, isolated acid reflux was significantly more common in the NERD group (Figure 1).

The relationship between DGER and the severity of esophageal lesions

The incidence of DGER in patients with grades A, B, C and D reflux esophagitis was $67 \%, 68 \%, 80 \%$ and $100 \%$, respectively. The results showed that the prevalence of DGER rose with the increased severity of esophageal lesions.

\section{DISCUSSION}

Traditional teaching has held that hydrochloric acid and pepsin are the primary reflux agents that cause both the esophageal symptoms and esophageal mucosal injury associated with GERD. However, this emphasis does not always explain common clinical observations such as the poor correlation between symptoms and mucosal injury and lack of clinical symptom improvement in patients receiving seemingly adequate acid suppressive therapy $(16,17)$. In recent years, Bilitec 2000 has been applied to detect DGER in an ambulatory setting, and it is believed to be the most accurate and objective assessment technique widely accepted in clinical practice $(1,4,5)$.

Previous studies (1) have shown that conjugated bile acids and pepsin were more injurious to the esophageal mucosa at acidic $\mathrm{pH}$, and unconjugated bile acids and trypsin were more harmful at $\mathrm{pH} 5$ to 8 . It was found that bile reflux could cause cell membrane damage and, consequently, increased esophageal mucosal permeability. Severe DGER usually occurred after the partial gastrectomy and the DGER severity

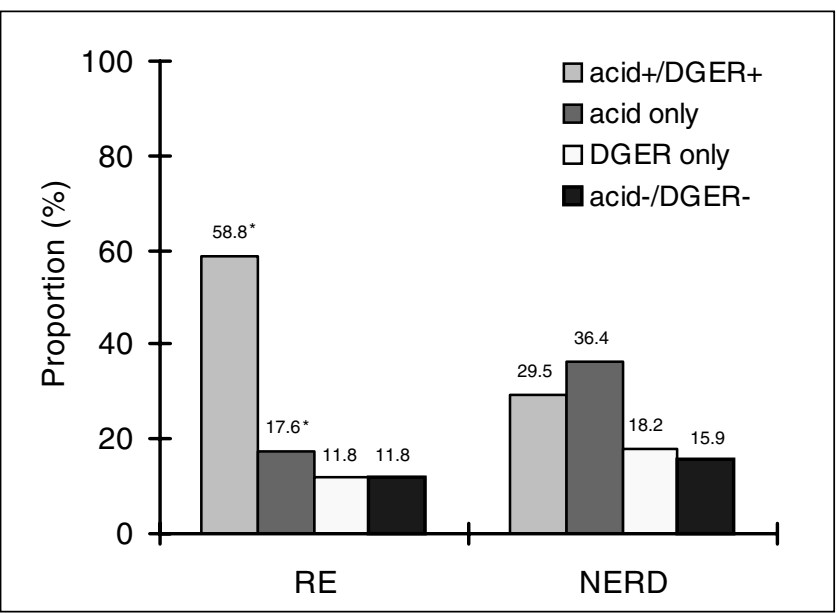

Figure 1) Proportion of esophageal acid reflux and duodenogastroesophageal reflux (DGER) in nonerosive reflux disease (NERD) and reflux esophagitis (RE) groups. Based on the above results, the positive diagnostic rate of NERD was $65.9 \%$ if patients just underwent $24 \mathrm{~h}$ esophageal $\mathrm{pH}$ monitoring. If simultaneous ambulatory $24 \mathrm{~h}$ esophageal $\mathrm{pH}$ and Bilitec (Synetics Medical, Sweden) monitoring were performed, the positive diagnostic rate of NERD would rise significantly to $84.1 \%(P<0.05) .+$ positive; - negative. ${ }^{*} P<0.05$ compared with NERD group

was associated with esophagitis and BE metaplasia (18). Nehra et al (19) reported that the concentration of bile acid was found to be significantly higher in RE and BE patients than in controls, and a temporal relation existed between reflux of taurine conjugates and esophageal acid exposure. Therefore, it is reasonable to surmise that coexistence of DGER and acid reflux may cause more severe damage and a greater risk of promoting development of metaplasia. But what are the effects of DGER alone on GERD? It was previously believed that DGER alone could not cause reflux esophagitis. Recently, Yumiba et al (20) found that RE occurred in 24 of 30 cases without gastric acid after total gastrectomy. The percentage total time of esophageal bilirubin absorbance greater than 0.14 was over $50 \%$ in all RE subjects using Bilitec monitoring. These results suggest that long-term esophageal bile exposure plays an important role in the genesis of RE in the absence of gastric acid.

In the present study, we found that $70.6 \%$ of RE patients had DGER, 58.8\% had concurrent DGER and acid reflux, and the parameters of DGER in RE group were significantly higher than in the NERD group. In addition, the incidence of DGER correlated with the severity of esophagitis. Therefore, our results emphasize the importance of DGER in causing RE, especially synergistically with acid, and that the severity of RE positively correlates with the degree of DGER.

Persistent and prominent DGER tends to be observed in partial gastrectomy patients. Generally, esophagitis developed in the mixed reflux conditions, and DGER occurred in no reflux conditions. After administration of drug or antibilereflux surgery in these patients, symptoms could relieve adequately (21). Tack et al (22) reported that among patients who responded poorly to proton pump inhibitor therapy, $38 \%$ had simple DGER, 26\% had both acid reflux and DGER, and only $11 \%$ had isolated acid exposure. 
Under some other situations, DGER may not play a major role in producing typical esophageal symptoms. Koek et al (23) reported that from a total of 544 symptom episodes, $28 \%$ were associated with acid reflux, 9\% with DGER and 12\% with mixed reflux. A positive symptom index for acid reflux was presented in $21 \%$ of the patients and for DGER in $14 \%$. The results of the present study are similar to that of Koek's study. DGER alone was presented in $18.2 \%$ of the NERD subjects, while the acid reflux alone was $36.4 \%$, twice the frequency of DGER. These results suggest that the symptoms can develop in the situation of DGER alone for a fraction of the total number of patients, but for most of patients the mechanism was due to acid reflux and mixed reflux.

GERD patients comprise a heterogeneous group of patients with NERD, RE and BE (9). It is the patients with many symptoms, but no endoscopic evidence of esophageal mucosal involvement, that are the most difficult to diagnose. Ambulatory $\mathrm{pH}$ monitoring provides a lower positive rate in these NERD patients than in RE and BE patients. There is no gold standard for the diagnosis of NERD, which is a diagnostic challenge (10-12). We note that DGER may cause symptoms

\section{REFERENCES}

1. Vaezi MF, Richter JE. Duodenogastroesophageal reflux and methods to monitor nonacidic reflux. Am J Med 2001;111(Suppl 8A):160S-8S.

2. Galmiche JP, Janssens J. The pathophysiology of gastro-oesophageal reflux disease: An overview. Scand J Gastroenterol Suppl 1995;211:7-18.

3. Singh S, Bradley LA, Richter JE. Determinants of oesophageal 'alkaline' $\mathrm{pH}$ environment in controls and patients with gastrooesophageal reflux disease. Gut 1993;34:309-16.

4. Vaezi MF, Lacamera RG, Richter JE. Validation studies of Bilitec 2000: An ambulatory duodenogastric reflux monitoring system. Am J Physiol. 1994;267:G1050-7.

5. Stipa F, Stein HJ, Feussner H, Kraemer S, Siewert JR. Assessment of non-acid esophageal reflux: Comparison between long-term reflux aspiration test and fiberoptic bilirubin monitoring. Dis Esophagus 1997;10:24-8.

6. Wang W, Xu GM, Li ZS, Zou D, Yin N. [The role of detecting bile reflux in the diagnosis of gastroesophageal reflux disease.] Zhonghua Nei Ke Za Zhi 1999;38:242-4.

7. Lin JK, Hu PJ, Li CJ, et al. [The role of 24-hour esophageal $\mathrm{pH}$ and bilirubin monitoring in the diagnosis of duodeno gastroesophageal reflux.] Chin J Dig 2001;21:602-4.

8. Zhang J, Yang ZX. [Role of acid reflux and bile reflux in the gastroesophageal reflux disease.] J Gastroenterol 2000;5:207-10.

9. Fass R, Ofman JJ. Gastroesophageal reflux disease - should we adopt a new conceptual framework? Am J Gastroenterol 2002;97:1901-9.

10. Fass R, Fennerty MB, Vakil N. Nonerosive reflux disease - current concepts and dilemmas. Am J Gastroenterol 2001;96:303-14.

11. Martinez SD, Malagon IB, Garewal HS, Cui H, Fass R. Non-erosive reflux disease (NERD) - acid reflux and symptom patterns. Aliment Pharmacol Ther 2003;17:537-45.

12. Kahrilas PJ. Diagnosis of symptomatic gastroesophageal reflux disease. Am J Gastroenterol 2003,98(3 Suppl):S15-23.

13. Chinese Gastroesophageal Reflux Disease Study Group. [The value of reflux disease questionnaire in the diagnosis of gastroesophageal reflux disease.] Chin J Dig 2003;23:651-4.

14. Cuomo R, Koek G, Sifrim D, Janssens J, Tack J. Analysis of and simultaneous $24 \mathrm{~h}$ esophageal $\mathrm{pH}$ and Bilitec monitoring can detect the nonacid reflux and improve the diagnostic rate. In the present study, $18.2 \%$ of NERD cases occurred with DGER, the diagnostic rate was $65.9 \%$ using $\mathrm{pH}$ monitoring and it significantly increased up to $84.1 \%$ using simultaneous Bilitec monitoring. Therefore, Bilitec monitoring could identify more NERD patients and played an important role in the diagnosis.

Few studies about the normal upper limit value of DGER have been performed in China. We determined the pathological DGER standard with bilirubin absorbance greater than 0.14 and the percentage of the time less than or equal to $2.53 \%$. This is similar to Zhang and Yang's report (8). Another reported normal value is less than or equal to $1.9 \%$ (7). In Western countries, however, a higher normal value was used. For example, Freedman et al (24) used the value of $7.7 \%$, and Tack et al (22) used $4.6 \%$ as a criterion for pathological DGER. Given these uncertainties and the as of yet limited use of this technology in general clinical practice, more prospective studies are needed to further characterize DGER and the relationship between this condition and GERD.

ambulatory duodenogastroesophageal reflux monitoring. Dig Dis Sci 2000;45:2463-9.

15. Tack J, Bisschops R, Koek G, Sifrim D, Lerut T, Janssens J. Dietary restrictions during ambulatory monitoring of duodenogastroesophageal reflux. Dig Dis Sci 2003;48:1213-20.

16. Holloway RH, Dent J, Narielvala F, Mackinnon AM. Relation between oesophageal acid exposure and healing of oesophagitis with omeprazole in patients with severe reflux oesophagitis. Gut 1996;38:649-54.

17. Katzka DA, Paoletti V, Leite L, Castell DO. Prolonged ambulatory $\mathrm{pH}$ monitoring in patients with persistent gastroesophageal reflux disease symptoms: Testing while on therapy identifies the need for more aggressive anti-reflux therapy. Am J Gastroenterol 1996;91:2110-3.

18. Dresner SM, Griffin SM, Wayman J, Bennett MK, Raimes SA. Human model of duodenogastro-oesophageal reflux in the development of Barrett's metaplasia. Br J Surg 2003;90:1120-8.

19. Nehra D, Howell P, Williams CP, Pye JK, Beynon J. Toxic bile acids in gastro-oesophageal reflux disease: Influence of gastric acidity. Gut 1999;44:598-602.

20. Yumiba T, Kawahara H, Nishikawa K, Inoue Y, Ito T, Matsuda H. Impact of esophageal bile exposure on the genesis of reflux esophagitis in the absence of gastric acid after total gastrectomy. Am J Gastroenterol 2002;97:1647-52.

21. Sears RJ, Champion GL, Richter JE. Characteristics of distal partial gastrectomy patients with esophageal symptoms of duodenogastric reflux. Am J Gastroenterol 1995;90:211-5.

22. Tack J, Koek G, Demedts I, Sifrim D, Janssens J. Gastroesophageal reflux disease poorly responsive to single-dose proton pump inhibitors in patients without Barrett's esophagus: Acid reflux, bile reflux, or both? Am J Gastroenterol 2004;99:981-8.

23. Koek GH, Tack J, Sifrim D, Lerut T, Janssens J. The role of acid and duodenal gastroesophageal reflux in symptomatic GERD. Am J Gastroenterol 2001;96:2033-40.

24. Freedman J, Lindqvist M, Hellstrom PM, Granstrom L, Naslund E. Presence of bile in the oesophagus is associated with less effective oesophageal motility. Digestion 2002;66:42-8. 


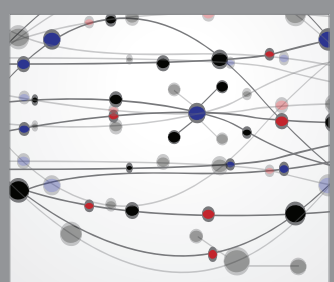

The Scientific World Journal
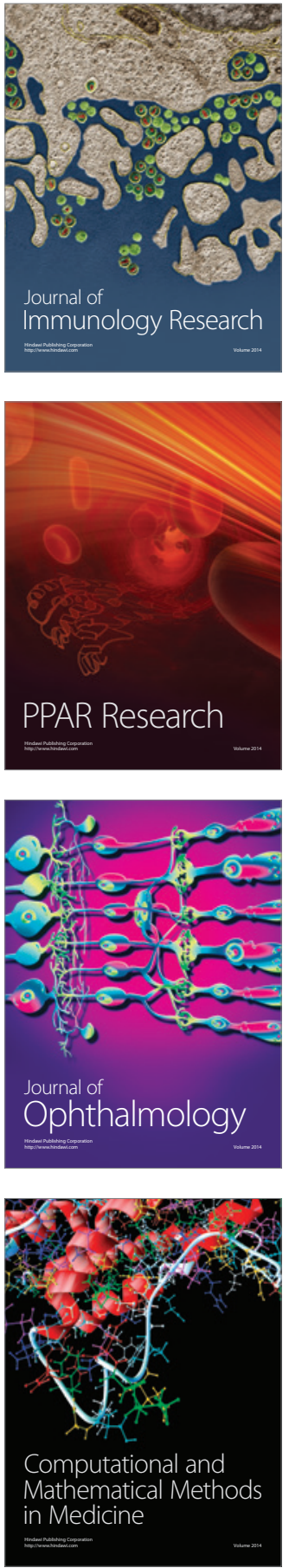

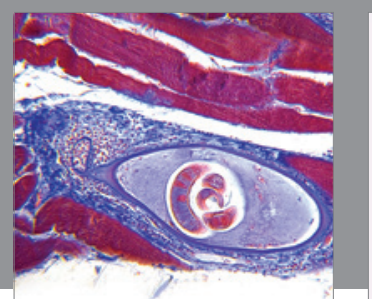

Gastroenterology Research and Practice

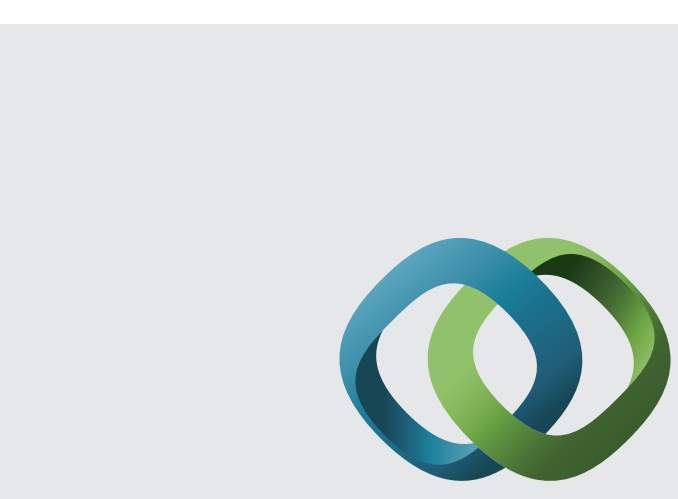

\section{Hindawi}

Submit your manuscripts at

http://www.hindawi.com
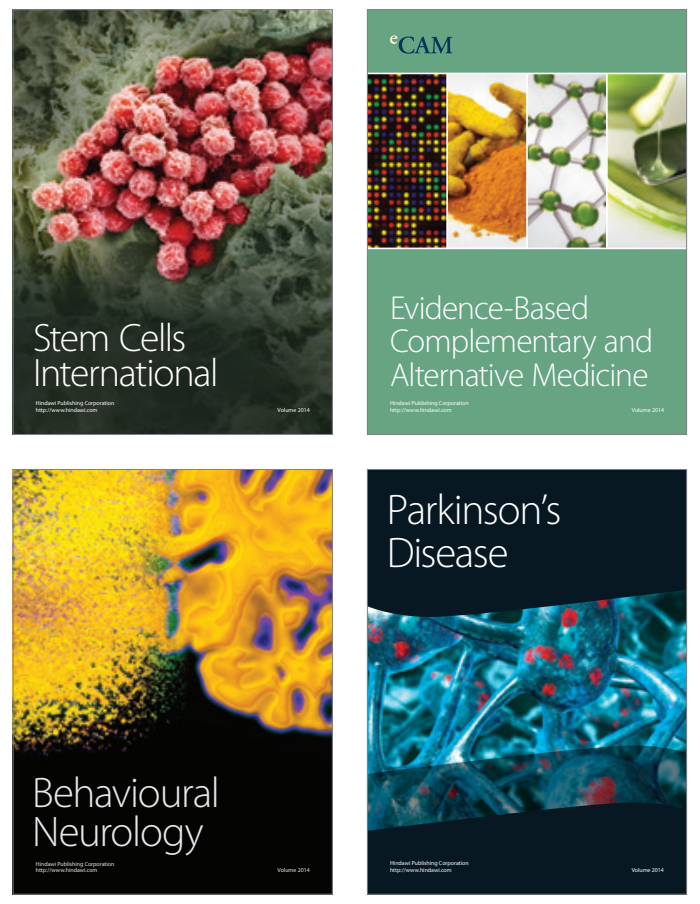
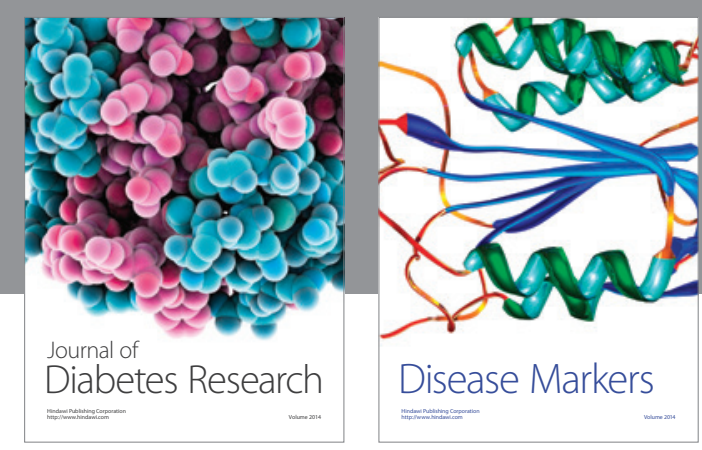

Disease Markers
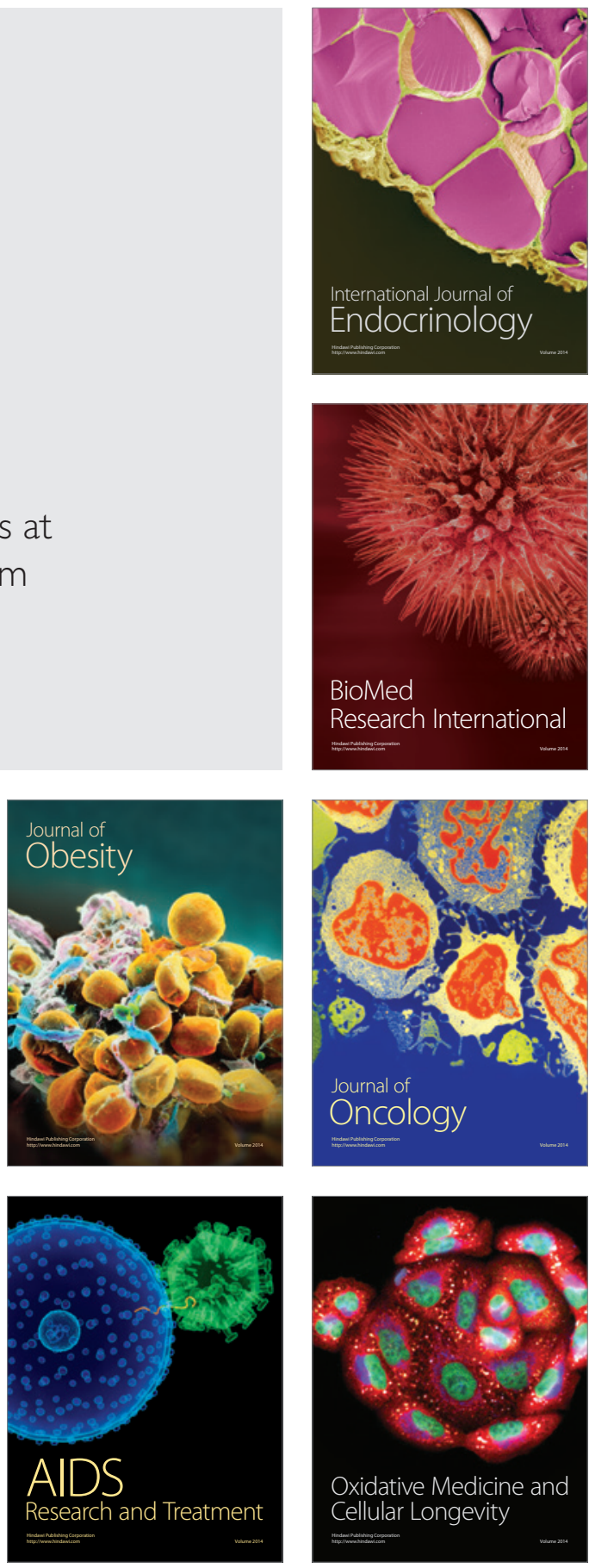